\title{
River habitat homogenisation enhances trophic competition and promotes individual specialisation among young of the year fish
}

\author{
Adrien Latli $^{1}$ (D) | Loïc N. Michel ${ }^{2, *}$ (D) | Gilles Lepoint ${ }^{2}$ (D) | Patrick Kestemont ${ }^{1}$ (I)
}

${ }^{1}$ Research Unit in Environmental and Evolutionary Ecology (URBE), Research Institute Life, Earth \& Environment (ILEE), University of Namur, Namur, Belgium

${ }^{2}$ Laboratory of Oceanology, MARE

Centre, University of Liege, Liege, Belgium

\section{Correspondence}

Adrien Latli, Research Unit in Environmental and Evolutionary Biology, University of

Namur, Namur, Belgium.

Email: adrien.latli@unamur.be

\section{*Present address}

Loïc N. Michel, Ifremer, Centre de Bretagne, REM/EEP, Laboratoire

Environnement Profond, Plouzané, France

Funding information

Fonds De La Recherche Scientifique -

FNRS; Public Service of Wallonia; European Fisheries Fund, Grant/Award Number: FEP 32-1109-004

\section{Abstract}

1. In large rivers, fish ontogenic development success is mainly influenced by resource availability and by the possibility of species to adapt their diet (i.e. trophic niche). Humans have drastically modified freshwater habitats, notably for navigation purposes. Such modifications may reduce food availability for young of the year (YOY) fish and, consequently, influence their ability to reach the adult age.

2. In the Meuse River, decrease of fish abundance is thought to be linked to a drastic reduction of phytoplankton biomass. In this context of decreasing phytoplankton biomass, we studied trophic niches of three cyprinid species (common bleak Alburnus alburnus, chub Squalius cephalus, and roach Rutilus rutilus) and one percid species (European perch Perca fluviatilis) at various stages of development, using stable isotope analysis in order to compare intra- and interspecific competition between sites differing in degree of channelisation.

3. Two reaches of the Meuse River differing by their degree of regulation were investigated. We hypothesised that habitat homogenisation would (1) decrease food resource availability and diversity and (2) increase trophic competition, particularly among earlier ontogenic stages, and promote individual specialisation.

4. Our study provides evidence that in the context of low planktonic biomass, most YOY relied on benthic food sources. Furthermore, the Meuse River flow and depth regulation significantly impacted the abundance and species richness of YOY. In the heavily channelised reach, between-stages competition and low resource diversity lead to an increase in diet partitioning between cyprinid larvae, as well as consumption of non-optimal energetic food sources such as aquatic vegetation by some individuals.

5. By contrast, in the less channelised reach, larvae displayed a generalist feeding habit focusing on high energy content prey such as different taxa of macroinvertebrates, suggesting that the diversity of habitat reduces the food competition within and between stages.

6. Intraspecific resource repartition is a key point for YOY fish having to cope with plankton-depleted conditions. Younger cyprinid stages seem more affected by intra- and inter-specific competition in the more channelised reach. YOY fish communities were also less diversified and abundant in the more altered site, which 
highlight the importance of limiting channelisation to better conserve fish communities.

\section{KEYWORDS}

conservation/biodiversity, food webs, Ontogeny, river regulation, stable isotopes

\section{1 | INTRODUCTION}

Pianka (1981) developed a theory popular among ecologists describing the trophic competition between species as the proportion of overlap between their trophic niches. In most cases, when resources and environmental variability decrease, trophic niche overlap tends to increase, which could lead in the most severe situations to competitive exclusion. This typically happens when introduced taxa occupy a new biotope and out-compete their trophic competitors (Ward \& Ricciardi, 2007). This is the case in freshwater systems where exotic Dreissenidae mussels (Dreissena polymorpha and Dreissena bugensis) or Corbiculidae have been shown to reduce populations of other large filter-feeding taxa such as Sphaeriidae and Unionidae (Marescaux et al., 2016). However, if food is abundant, two species could share the same resources without negatively impacting each other (Pianka, 1974). For example, omnivorous fish suffer less from river regulation and habitat destruction than fish having more specialised diets (Aarts, Van Den Brink, \& Nienhuis, 2004; Latli, Descy, et al., 2017).

Although food web models are traditionally used to determine trophic interactions between species, several studies have shown that dietary variation may occur within populations or species (Bolnick et al., 2003). Indeed, a generalist species or population consuming a large range of resources may be composed of many individuals specialised on small subsets of food items that differ among individuals. These individual specialists could play their own ecological roles in terms of trophic relationships and habitat use (Yurkowski et al., 2016). Trophic individual specialisation (IS) is influenced by trophic competition (intra- and/or inter-specific), prey diversity and/ or abundance, and predation pressure (Araújo, Bolnick, \& Layman, 2011). According to the optimal foraging theory (MacArthur \& Pianka, 1966), in a system with unlimited food resources, consumers may share preferred resources, decreasing the IS of the population. In contrast, decreasing trophic resources may result in a higher intraspecific competition for the preferred diet. Scarcity of preferred items could, in turn, force consumers to add alternative resources to their diets, increasing the degree of IS (Kernaléguen, Arnould, Guinet, \& Cherel, 2015).

Individual specialisation has been well documented for species living in a large number of ecosystems (Araújo et al., 2011), but food web studies have rarely taken into account the ontogeny of individuals, which implies the assumption that food resources are more or less similar for all life stages (Rudolf \& Lafferty, 2011). However, trophic interactions develop during the ontogeny of numerous species, with crucial consequences for populations but also for the entire food web (Nakazawa, 2015). The large majority of species with larvae feeding autonomously (invertebrates, fish, amphibians) have at least one diet shift in their early life. In freshwater, the majority of young fish larvae preferentially consume small zooplankton as rotifers, and small cladocera, which are the optimal diet in terms of cost/benefit ratio after yolk sac resorption (Nunn, Harvey, \& Cowx, 2007a). This diet can be completed by small insects and phytoplankton. The diet of older larvae is generally more diversified: juveniles typically shift to benthic macroinvertebrate prey, with an herbivory complement according to the species, when fin development enables greater swimming performance (Nunn, Tewson, \& Cowx, 2012).

As with many European rivers, such the Rhone, Danube, and Rhine, the Meuse River has been heavily regulated for navigation and flood control, mainly in the Belgian section (Descy, 2009). River channelisation and riparian land use reduce the inputs of terrestrial matter usable by the macroinvertebrate community (Lecerf, Baudoin, Besson, Lamothe, \& Lagrue, 2012) while dams homogenise habitats by modifying erosion and sediment transport and deposition (Aarts et al., 2004). In the deepened sections of regulated rivers, the development of benthic primary producers has been reduced by light limitation and habitat has been altered by removal of gravel deposits and macrophyte stands. By contrast, habitats of the French section of the Meuse River have been less disturbed, conserving their ecological functions and biodiversity. The shallowness of the French section of the river allows the development of diverse aquatic and subaquatic vegetation, from periphyton to helophytes and hydrophytes. The riparian zone is quite well developed and contributes to increased habitat heterogeneity (Descy, 2009).

A major event in the recent history of the Meuse River was the establishment of non-native filter-feeding bivalves, dreissenid and corbiculid mussels, which contributed to reduce the phytoplankton and zooplankton biomass by $85 \%$ over a period of 15 years (Pigneur et al., 2014). As in many European and American freshwater ecosystems (Higgins, Vander Zanden, Joppa, \& Vadeboncoeur, 2011; Ward $\&$ Ricciardi, 2007), the invasive filter-feeders have impacted most biota in the Meuse River, from plankton to piscivorous fish (Latli, Descy et al., 2017). However, the impact on fish communities varied according to the degree of channelisation. In the Belgian part of the river, the biomass of some species such as roach (Rutilus rutilus), which dominated the community during the 1990s, was reduced by $85 \%$, mainly as a result of the collapse of the water column resources (Otjacques, De Laender, \& Kestemont, 2016; Otjacques et al., 2015). By contrast, in the less regulated part of the Meuse River in France, the stock of roach remained constant (Alonso, Mougenez, \& Delattre, 2014). 
TABLE 1 Physical description of two sites of the Meuse River (Ham-sur-Meuse in France and Waulsort in Belgium)

\begin{tabular}{|c|c|c|c|c|c|c|}
\hline Site & $\begin{array}{l}\text { Distance from } \\
\text { source }(\mathrm{km})\end{array}$ & Catchment $\left(\mathrm{km}^{2}\right)$ & Chanel width (m) & $\begin{array}{l}\text { Water discharge (annual } \\
\text { average } \mathrm{m}^{3} / \mathrm{s} \text { ) }\end{array}$ & Altitude $\pm 5 \mathrm{~m}$ & Slope $(/ 1,000)$ \\
\hline Ham/Meuse & 469 & 10,110 & 100 & 148 & 105 & 0.13 \\
\hline Waulsort & 489 & 10,584 & 120 & 152 & 95 & 0.25 \\
\hline
\end{tabular}

In this study, we used stable isotopes to compare the trophic ecology of differing developmental stages of four fish species in two differently regulated reaches of the Meuse River, in a context of low phytoplankton availability. We hypothesised that the habitat heterogeneity in the less channelised reach would offer greater food resource availability and diversity, which would increase the abundance of young of the year (YOY) fish. We delineated the diet of fish by ontogenic stages to identify the alternative exploited resources and we hypothesised that trophic competition would be stronger among earlier ontogenic stages, with a greater degree of IS in the channelised reach.

\section{2 | METHODS}

\section{1 | Study area}

The Meuse River rises on the Langres plateau in north-eastern France, flows through Belgium and Netherlands, and ends up in the Dutch delta after joining the Lower Rhine. The total length of the river is close to $925 \mathrm{~km}$ for a catchment area of $36,011 \mathrm{~km}^{2}$. The main characteristics of the river basin and of the river itself were summarised by Descy (2009). The present study was conducted in two reaches of the Meuse River located 469 and $488 \mathrm{~km}$ from the source (Table 1). The first site (France) is not channelised and navigation is not allowed. The flow is controlled by old-fashioned weirs that generally maintain shallow and fast-flowing reaches, allowing the development of aquatic and subaquatic mosses and higher plants. The bank is near-natural in most stretches and a riparian zone of small width is well developed on a long range of river (Ham-sur-Meuse; $\mathrm{N}$ $50^{\circ} 6^{\prime} 36^{\prime \prime}$, E 4 ${ }^{\circ} 46^{\prime} 49$ ). The second site (in Belgium) is a heavily channelised reach allowing navigation of 1,600-ton barges. The water level is regulated by automatic weirs which maintain a relatively high-water depth. Frequent and heavy dredging of the river bed as well as concrete and stone banks considerably reduces the development of aquatic and riverine vegetation as well as habitat heterogeneity (Waulsort; N 50¹2'56", E 449'37").

During the last 25 years on the French and Belgian Meuse River, water temperature increased almost $1^{\circ} \mathrm{C}$ whereas orthophosphate, nitrate, and suspended matter concentrations decreased (Latli, Descy et al., 2017) along with phytoplankton biomass, which fell by 85\% (Figure 1). The zooplankton followed the same trend: during the 1990s the mean abundance of Rotifera was between 300 and 500 individuals (ind)/L through the summer with maxima close to 4,000 ind/L. After 2010, the maximal abundance was lower than 100 ind/L (L. Viroux, unpublished data).

Benthic macroinvertebrate abundance is similar in the two studied sites (Latli, Descy et al., 2017). The family richness is slightly higher at

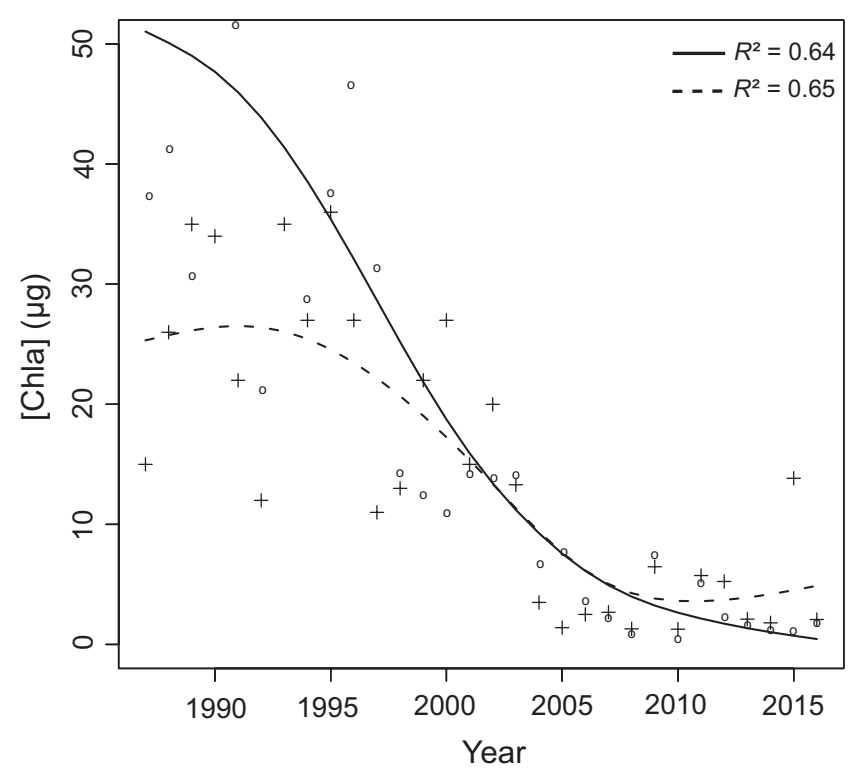

FIGURE 1 Long-term variation in the annual mean values of chlorophyll-a ( $\mu \mathrm{g} / \mathrm{L}$ ) in the Meuse River between 1987 and 2016. Temporal trends were modelled using a generalised additive model with residual autocorrelation structure. Solid line and dots correspond to Ham-sur-Meuse (France) and dashed line and crosses to Waulsort (Belgium). (Data sources: Water Agency Rhin-Meuse, Public Service of Wallonia and WAter CONtrol DAta system for hydrology and water management)

Waulsort (28) than at Ham-sur-Meuse (25) mainly due to exotic taxa that represent $>80 \%$ of the sampled organisms. In the channelised section in Belgium, the benthic invertebrate assemblage is dominated by crustaceans (e.g. Asellidae, Chelicorophium sp. and Dikerogammarus sp.), molluscs (e.g. Corbiculidae, D. polymorpha), and Oligochaetes. Pigneur et al. (2014) reported that invasive filter-feeders can reach densities between 50 and 900 individuals per square meter. In the French site, we find many taxa with preferences for fast-flowing conditions (e.g. Ephemeridae, Coleoptera, and Diptera). The number of invertebrate scrapers has strongly increased in France in relation with phytoplankton decrease, which resulted in an improvement of water transparency, promoting periphyton and macrophyte growth in the shallowest parts of the river (Latli et al., 2018).

\subsection{Sampling and isotope measurements}

\subsection{1 | Sampling protocol}

Potential food sources and fish were sampled at both sites every 2 weeks from April to September in 2013 and 2014. Aquatic 
vegetation (algae, bryophytes, hydrophytes, periphyton), terrestrial vegetation (bank and litter), planktonic resources (FPOM: fine particulate organic matter-particle size 0.6-30 $\mu \mathrm{m}$; and CPOM: coarse particulate organic matter-particle size 30-100 $\mu \mathrm{m}$ ), macroinvertebrates (Diptera, Ephemeroptera, Crustacea...), and young of the year fish were sampled as potential food sources (Supporting Information Appendix S1). Macroinvertebrates were sampled with a Surber sampler (mesh size $500 \mu \mathrm{m}$ ) along the banks and by scuba diving in the channel. By successive filtration, we separated planktonic resources into two potential food sources according to their sizes, from 0.6$30 \mu \mathrm{m}$ for fine particulate organic matter and 30-150 $\mu \mathrm{m}$ for coarse particulate organic matter. Thirty $\mu \mathrm{m}$ is the theoretical upper size limit of consumable preys by the invasive mollusc Corbicula fluminea (Way, Hornbach, Miller-Way, Payne, \& Miller, 1990).

Every 2 weeks, 40 sampling points were randomly selected in the same part of the reach where potential food sources were collected. Young of the year fish were caught using the point abundance sampling by electrofishing approach from a boat along the banks, with a $7 \mathrm{~kW}$ generator delivering a continuous current (150-300 V at 3A) as proposed by Copp (2010). Electrofishing from boat was also carried out to sample adult fish along the banks over multiple habitats and a distance of $800-1,000 \mathrm{~m}$. We used a more powerful generator (400 $\mathrm{V}$ at 5A, DEKA 7000) to maximise the catch efficiency of large individuals.

Fish were anesthetised and euthanised using an excess of 2-phenoxyethanol ( $3 \mathrm{ml} / 10 \mathrm{~L}$ freshwater) according to ethical requirements, then rinsed with deionised water and frozen in an Eppendorf tube. All fish were identified at the species level using a key (Pinder, 2001). Individuals were grouped into three classes (larvae, juvenile, and adult), according to their morphological development. We considered as larvae the newly hatched fish with no remaining yolk sac and with dorsal fin rays in development, and juveniles as individuals with fins sufficiently well developed to allow swimming in open water (see Pinder, 2001 for more information). We considered specimens as adults when they were older than 1 year, based on their length. The term YOY includes individuals at the larval and juvenile stages.

A total of 8,162 fish (7,914 YOY and 248 adults) from 20 species were caught and identified. Common bleak (Alburnus alburnus), chub (Squalius cephalus), roach (Rutilus rutilus), and European perch (Perca fluviatilis) represented $78 \%$ of the total individuals sampled. Isotopic analyses were carried out only on these four species. At each site and for every sampling date, whenever possible, we randomly selected up to 30 YOY per species for isotopic analysis (common bleak: $n=214$, chub: $n=635$, roach: $n=652$ and European perch: $n=101$ ). After measuring the total length to the nearest $\mathrm{mm}$, a sample of lateral muscle tissue of each fish was used for stable isotope analysis. Each consumer and potential food source samples were dried individually at $60^{\circ} \mathrm{C}$ for at least $48 \mathrm{hr}$ and ground into a homogenous fine powder using a mortar and a pestle. Stable isotope ratio measurements were performed via continuous flow-elemental analysis-isotope ratio mass spectrometry at University of Liège, using a vario MICRO cube elemental analyser (Elementar Analysensysteme
$\mathrm{GmBH}$, Hanau, Germany) coupled to an IsoPrime100 mass spectrometer (Isoprime, Cheadle, UK). Isotopic ratios were expressed using the widespread $\delta$ notation (Coplen, 2011). Sucrose (IAEA-C6, $\delta^{13} \mathrm{C}=-10.8 \pm 0.5 \%$, mean $\pm S D$ ) and ammonium sulfate (IAEA-N2, $\delta^{15} \mathrm{~N}=20.3 \pm 0.2 \%$, mean $\pm S D$ ) were used as certified reference materials. Both of these reference materials are calibrated against the international isotopic references, i.e. Vienna Pee Dee Belemnite for carbon and atmospheric air for nitrogen. Standard deviations on multi-batch replicate measurements of lab standards (fish tissues) analysed interspersed among the samples (two laboratory standards for 15 samples) were $0.1 \%$ for $\delta^{13} \mathrm{C}$ and $0.3 \%$ for $\delta^{15} \mathrm{~N}$.

\section{3 | Isotope metrics}

For the 12 fish groups (four species and three stages) composed by at least five individuals, isotopic niche parameters were computed using the SIBER package for R (Jackson, Inger, Parnell, \& Bearhop, 2011). SIBER was used to generate bivariate standard ellipses that represent core isotopic niches of consumers, as well as convex hulls that comprise all individuals of a $\delta^{13} \mathrm{C}$ and $\delta^{15} \mathrm{~N}$ isotope bi-plot (Layman, Quattrochi, Peyer, \& Allgeier, 2007). Areas of these ellipses were estimated using a computation method designed to minimise effects of small and/or uneven sample size $\left(\mathrm{SEA}_{C}\right.$, Jackson et al., 2011). The cumulative overlap between ellipses of the different fish groups illustrates the potential trophic competition among taxa at the site where samples were collected.

We calculated the contributions of potential food sources to each age class of each species' diet with the R-software (R 3.4 version, R Development Core Team, 2015) using the package MixSIAR (Stock \& Semmens, 2013). The isotopic variations of potential food sources were characterised by the mean of the taxa family $( \pm S D)$ and the abundance of each taxon analysed (Supporting Information Appendix S1). The MixSIAR models were constructed using trophic enrichment factors determined previously by the authors during a controlled experiment targeted on YOY of the studied species (Latli, Sturaro, et al., 2017) and with the formula proposed by Caut, Angulo, and Courchamp (2009) for adults. To reduce the number of potential food sources in the model, we pooled prey types if stable isotope values were not statistically different as proposed by Phillips et al. (2014).

In addition to age class analysis, MixSIAR was also used to compute relative prey contribution to the diet of each individual fish. This output was subsequently used to calculate the individual trophic specialisation of each fish species and age class using the method developed by Araújo, Bolnick, Machado, Giaretta, and dos Reis (2007) and Bolnick, Yang, Fordyce, Davis, and Svanbäck (2002) with the RInSp package (Zaccarelli, Bolnick, \& Mancinelli, 2013). For each fish group, we estimated the total niche width (TNW, a measure of population-level variance in diet) as the sum of diet variability within individuals (or within-individual component, WIC) and diet variability between individuals (). A smaller WIC than between-individual component is generally related to a specialist population. The ratio between WIC and TNW measured the degree of intra-population 
foraging specificity (also called individuality). A ratio close to 1 indicates that all individuals exploit the complete range of the population's niche, as opposed to populations that comprise individuals having narrower isotopic niches than the population considered as individual dietary specialists.

\section{4 | Statistical analysis}

Temporal trends of population indices (abundance, biomass, and specific diversity) were examined over the study period using generalised additive models (Fewster, Buckland, Siriwardena, Baillie, \& Wilson, 2000) and modelled as a smooth nonlinear function of time. Autocorrelation error was reduced by adding a residual autocorrelation structure, optimised by minimising the AIC criterion over several combinations of autoregressive parameters (Zuur, leno, Walker, Saveliev, \& Smith, 2009).

With a generalised linear model, we characterised the relation between population indexes with time and site interaction. We also used a generalised linear model to identify relations between isotopic indices (SEA $\mathrm{C}_{\mathrm{C}}$, Overlap, WIC/TNW) and the ontogenic stage, the species and the site. We realised the pairwise comparisons based on the Bonferroni adjustment with the Ismeans package (Lenth, 2016).

Normality of data and residuals were analysed with a ShapiroWilk test (Shapiro \& Wilk, 1965).

\section{3 | RESULTS}

In both studied sites, we first caught larvae with a resorbed yolk sac from April (Figure 2), with a maximum reached in May (18.5 larvae by
TABLE 2 Statistical evaluation of time and site effects with a generalised linear model for three population indices and young of the year abundances of four species caught at two sites of the Meuse River (Ham-sur-Meuse in France and Waulsort in Belgium) in 2013 and 2014

\begin{tabular}{|lccl} 
& \multicolumn{3}{l}{$p$-values } \\
\cline { 2 - 4 } & Site & Time & Site $\times$ Time \\
\hline Abundance & .054 & .048 & .002 \\
\hline Biomass & .005 & .001 & $<.001$ \\
\hline Species richness & .015 & $<.001$ & .005 \\
\hline Alburnus alburnus & $<.001$ & .008 & $<.001$ \\
\hline Squalius cephalus & .68 & .237 & .477 \\
\hline Rutilus rutilus & .689 & .013 & .099 \\
\hline Perca fluviatilis & $<.001$ & $<.001$ & $<.001$ \\
\hline
\end{tabular}

Bold values indicate statistical significance ( $p$-value $<.05)$.

$\mathrm{m}^{2}$ ). After this date, the total abundance of YOY communities varied depending on the site ( $p=.002$, Table 2$)$. In the most channelised site, YOY abundance strongly decreased while it remained constant until September at the less channelised station. The biomass and the species richness were significantly higher at Ham-sur-Meuse than at Waulsort, where they remained constant after a brief increase during the first months of the study (respectively $p<.001$ and $p=.005$ ). Larval mortality of the earliest spawning species was potentially offset by the hatching of later breeding taxa at Ham-sur-Meuse, but not at Waulsort. The abundance of chub and roach varied in a similar way over time at both stations studied, with a rapid increase followed by a steady decrease. By contrast, the abundance of the two
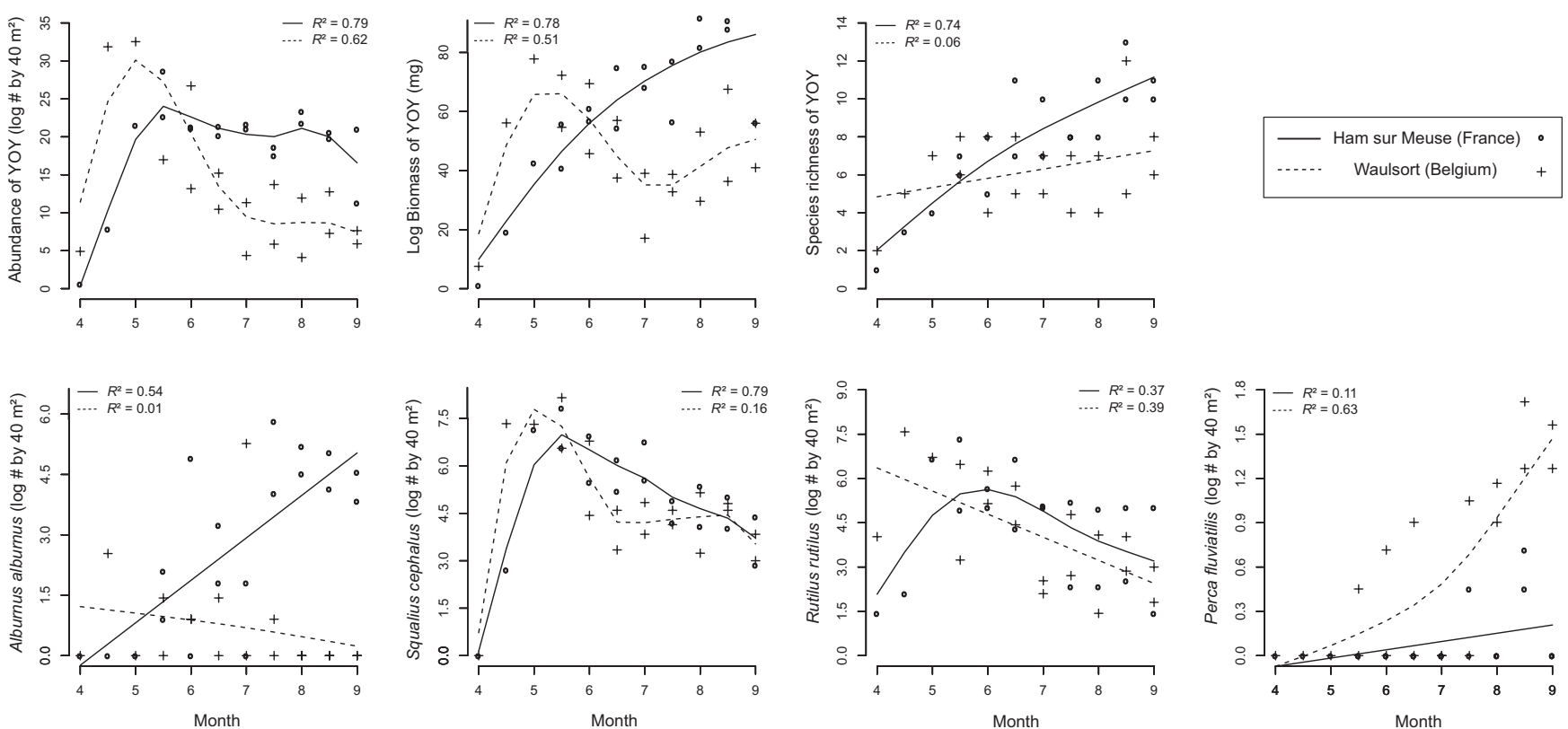

FIGURE 2 Temporal evolution of abundance, biomass and species richness of the young of the year (YOY) fish communities sampled at two sites of the Meuse River in 2013 and 2014. Abundances over time are shown separately for common bleak, chub, roach, and European perch YOY. Temporal trends were modelled using generalised additive models with residual autocorrelation structure. Solid line and dots correspond to the lightly channelised reach and dashed line and crosses to the heavily channelised reach 
other species differed according to the station: common bleak increased at Ham-sur-Meuse but not at Waulsort $(p<.001)$, whereas the contrary was observed for the European perch $(p<.001)$.

The diet of consumers for all stages of development was estimated with MixSIAR models (see Supporting Information Appendices S1-S3 for more details) for both sites. Benthic macroinvertebrates composed most of the diets of the four fish species (Figure 3a-c). Planktonic resources and terrestrial vegetation were minimal components of larvae, juveniles or adults' diets at both sites. During the early ontogenic stages, fish assimilated a larger part of aquatic vegetation, mainly algae (95\% credible interval [Cl]: 5-57), which tended to decrease as fish grew (95\% Cl: 2-45) in favour of fish prey, notably at Waulsort (95\% $\mathrm{Cl}$ : 9-74). At Ham-sur-Meuse, fish had a modelled diet mostly consisting of macroinvertebrates whereas at Waulsort, fish consumed larger quantities of aquatic vegetation and YOY (Figure 3c). However, the contribution of small YOY for larvae and juveniles was smaller for cyprinids than for juvenile European perch and for adults (except bleak).

The isotopic niche areas $\left(\mathrm{SEA}_{C}\right)$ and the niche overlaps of the 12 groups (four species and three stages) modelled with SIBER (see Supporting Information Appendix S4 for more details) did not differ between the studied sites, and the slopes of the regression between these two parameters were not significantly different, reflecting an absence of interaction with sites ( $p=.8$, Figure 4 ). This finding is confirmed by a post hoc test (Figure 5), which highlights that the isotopic niche overlaps between species were significantly wider during the early-life stage (larvae, $p<.001$ ) while the isotopic niche size $\left(S_{C A}\right)$ did not significantly differ (Figure 5 ). In both sites, niche overlap was greater during the larval stage.

At each ontogenic stage, the three species of cyprinid fish (common bleak, chub, and roach) had a niche overlap significantly higher than European perch $(p<.01)$, and two of the cyprinids depended on a greater diversity of resources than the perch (larger SEAc for chub, $p<.01$, and roach, $p<.05$ ).

By studying the diet of each individual (WIC) related to the group to which it belongs (TNW) we evaluated the relative degree of IS (individuality). The slope of the regression was significantly different between the two sites $(p<.001)$ which suggests that at least one studied group had a more specialised diet at Waulsort than at Ham-sur-Meuse (Figure 6). Individual specialisation appeared higher (and WIC lower) relative to total niche variation (TNW) at Waulsort, indicating that some specimens consumed prey which strongly differed from the rest of the population in the most channelised reach. The post hoc test established that larvae had a more specialised diet in the Belgian site than those of the French site $(p<.01$, Figure 7$)$. Furthermore, roach larvae were more generalist at Ham-sur-Meuse $(p<.05)$ than at Waulsort, and chub and bleak larvae tended to follow the same trend.

\section{DISCUSSION}

Ecological impacts of river regulation on habitat diversity and fish assemblages have been widely documented, but their role in the trophic competition between fish ontogenic stages has been poorly investigated so far (Mapes, DuFour, Pritt, \& Mayer, 2015; Wedderburn et al., 2017). In a low planktonic resource context, we hypothesised that the habitat heterogeneity potentially offers a greater resource availability and diversity, which increases the abundance of YOY fish and reduces trophic competition, notably during the earlier stages of development.

Our observations supported the hypothesis that river regulation potentially influences fish recruitment. Between April and June, abundance of YOY increased in a similar way at both sites. However, in the channelised reach, YOY abundance decreased afterwards, whereas it remained constant in the less regulated reach. This may be related to the later reproduction of other fish species as tench Tinca tinca, common carp Cyprinus carpio, minnow Phoxinus phoxinus, barbel Barbus barbus, or common bream Abramis brama, which compensated mortality of the early spawning species as roach and chub (Bass, Pinder, \& Leach, 1997; Pinder, 2001). Habitat diversity afforded by lateral connections and low mainstream regulation could improve fish recruitment by offering nursery habitat for a larger number of species, and potentially a wider diversity of food sources (Keckeis, Winkler, Flore, Reckendorfer, \& Schiemer, 1997; Konrad et al., 2016; Nagayama \& Nakamura, 2018; Reckendorder et al., 2001; Schiemer, Spindler, Wintersberger, Schneider, \& Chovanec, 1991). In the Great Ouse River, the recruitment of numerous species decreased and many cyprinid fish became locally extinct due to the river regulation and habitat homogenisation (Copp, 1997). In the Maumee River, lithophilic spawning fish and many cyprinid larvae benefited from the improvement of habitat quality and complexity (Mapes et al., 2015). In this study, habitat diversity did not impact the recruitment of the two generalist species, roach and chub, whose densities were comparable to other rivers (Valová, Jurajda, \& Janáč, 2006). This is in agreement with the report by Jurajda, Reichard, Hohausová, and Černý (2001) on rivers of the Danube basin, where river channelisation barely impacted limnophilic species. In contrast, rheophilic species as nase Chondrostoma nasus or spirlin bleak Alburnoides bipunctatus were more sensitive to river flow regulation, with the exception of chub, which was potentially better adapted to hydromorphological modifications (Valová et al., 2006).

The abundance of common bleak and European perch YOY differed in the Meuse River according to the studied reach. This divergence could be linked with the density of adult European perch which decreased over time in the French site, but remained constant in the Belgian section, while the opposite was observed for the common bleak (Alonso et al., 2014; Benitez, Dierckx, Nzau Matondo, \& Ovidio, 2015). In another study, we showed that plankton decline and increased predation risk (e.g. the great cormorant Phalacrocorax carbo and the European wels Silurus glanis) influenced trophic structure of the fish community of the Meuse River (Latli, Descy et al., 2017), which could potentially differ according to the diet type and the importance of human perturbation.

The temporal changes in YOY catches could also be attributed to deliberate dispersal movements. During early stages, fish disperse from nursery areas to appropriate rearing habitats (Lechner, Keckeis, 
(a)

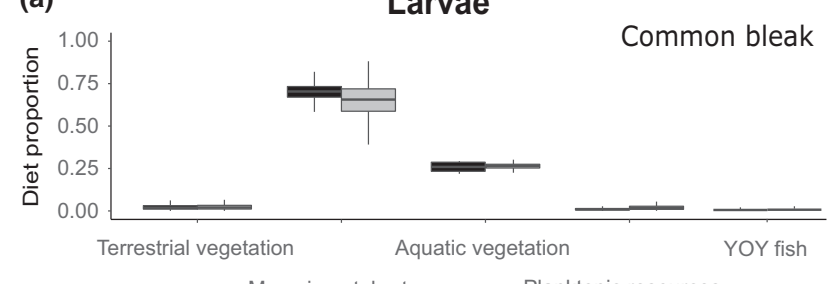

Macroinvertebrate Planktonic resources

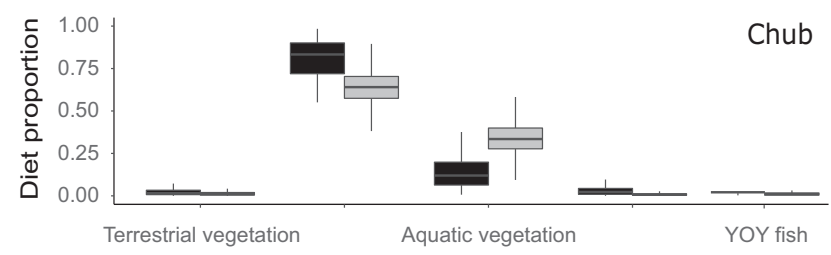

Macroinvertebrate Planktonic resources

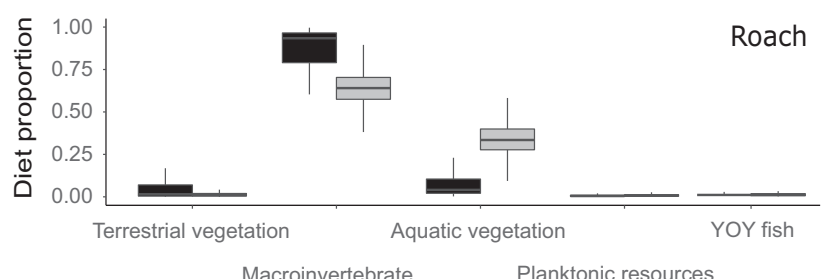

Potential food sources

Ham sur Meuse Waulsort

(c)

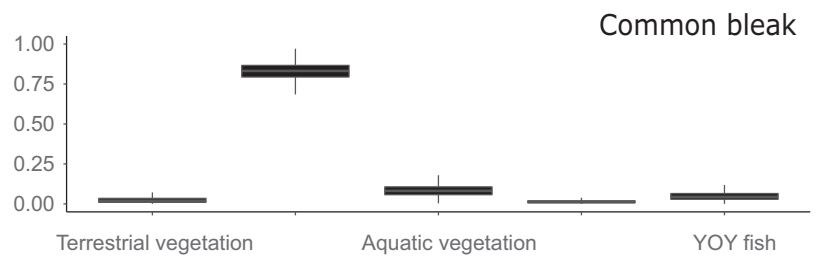

Macroinvertebrate Planktonic resources

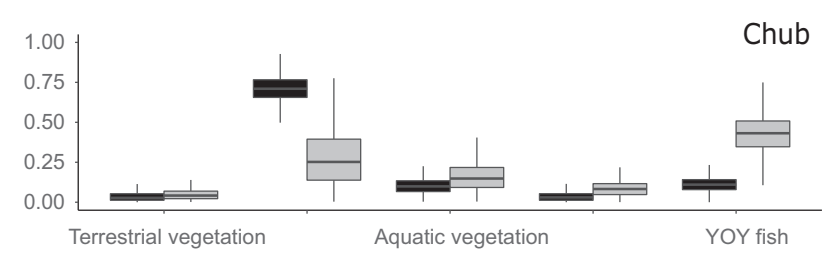

Macroinvertebrate Planktonic resources

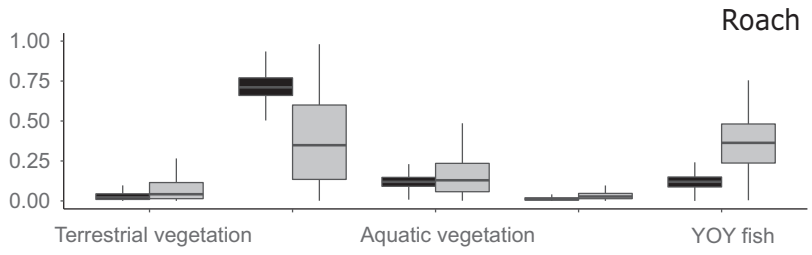

Macroinvertebrate Planktonic resources

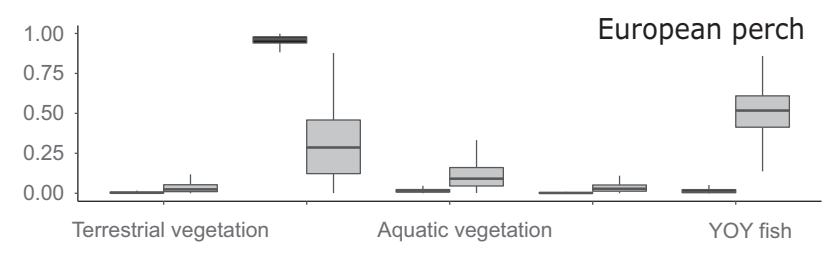

Macroinvertebrate Planktonic resources

Potential food sources (b) Juveniles

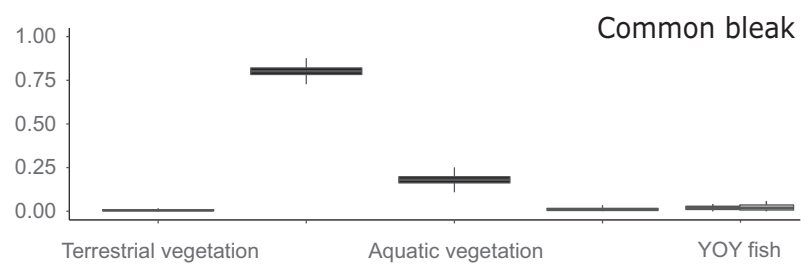

Macroinvertebrate Planktonic resources

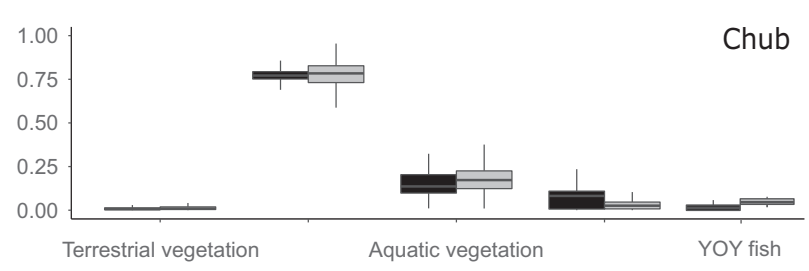

Macroinvertebrate Planktonic resources

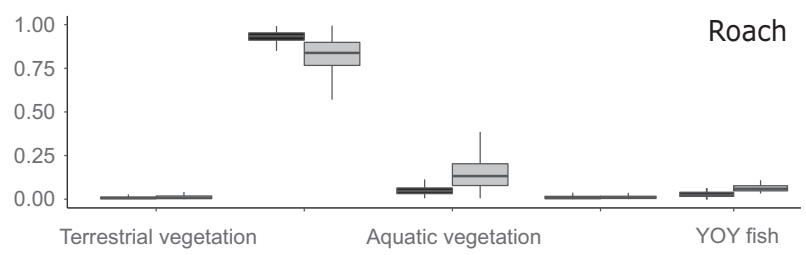

Macroinvertebrate Planktonic resources

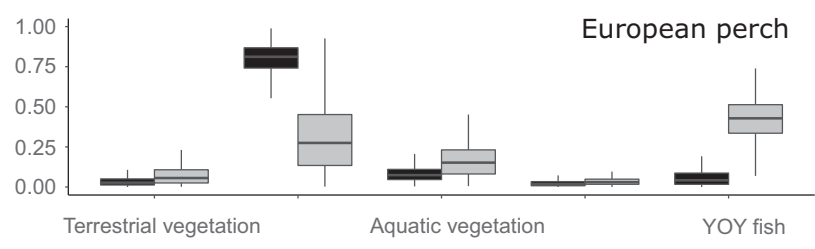

Macroinvertebrate Planktonic resources

Potential food sources 
FIGURE 3 (a) Diet composition, as depicted by the MixSIAR model, of four species of fish at larval stage, based on the individual $\delta^{13} \mathrm{C}$ (\%) and $\delta^{15} \mathrm{~N}(\% \circ)$ values and the potential food sources sampled at Waulsort and Ham-sur-Meuse between 2013 and 2014 (see Supporting Information Appendix S1 for details). Median: lines in centre of boxes, $50 \%$ credibility interval (Cl): box boundaries, $95 \% \mathrm{Cl}$ : error bars. (b) Diet composition, as depicted by the MixSIAR model, of four species of fish at juvenile stage, based on the individual $\delta^{13} \mathrm{C}(\% \circ)$ and $\delta^{15} \mathrm{~N}$ (\%) values and the potential food sources sampled at Waulsort and Ham-sur-Meuse between 2013 and 2014 (see Supporting Information Appendix S1 for details). Median: lines in center of boxes, 50\% Cl: box boundaries, $95 \% \mathrm{Cl}$ : error bars. (c) Diet composition, as depicted by the MixSIAR model, of four species of fish at adult stage, based on the individual $\delta^{13} \mathrm{C}(\% \circ)$ and $\delta^{15} \mathrm{~N}(\%)$ values and the potential food sources sampled at Waulsort and Ham-sur-Meuse between 2013 and 2014 (see Supporting Information Appendix S1 for details). Median: lines in center of boxes, $50 \% \mathrm{Cl}$ : box boundaries, $95 \% \mathrm{Cl}$ : error bars. YOY, young of the year

\& Humphries, 2016) mainly at night to reduce predation risk (Johnson \& McKenna, 2007). This dispersion could occur accidentally, following high flow episodes for example (Pavlov, Mikheev, Lupandin, \& Skorobogatov, 2008). The motivation of intentional drifting is not clearly addressed in the literature and may be stimulated by food availability or search for a specific habitat (Lechner et al., 2016) but, to our knowledge, there are no studies linking food quality or quantity to YOY drift events.

Young of the year fish are sensitive to environmental changes (Jurajda et al., 2001; Wedderburn et al., 2017) but also to food availability (Nunn, Harvey, \& Cowx, 2007b). In the Meuse River, the decrease of planktonic production has resulted in a diet shift of the four studied fish species, which turned to foraging in the benthos independently of the degree of channelisation and the abundance of riparian resources (Latli et al., 2018). Our results show that the diet of different cyprinid larvae and juveniles was mainly composed of benthic macroinvertebrates, with minor contributions of aquatic vegetation. Young of the year shift to benthic prey when planktonic prey decrease, which could indicate that benthic invertebrates were their optimal food sources in a low planktonic context (Nunn et al., 2012). A similar response has been reported by Hoogenboezem, Lammens, van Vugt, and Osse (1992) for the common bream under zooplankton abundance lower than 500 ind/L. For many cyprinids and percids, switching from water column feeding to a selective capture of benthic prey could decrease the relative energy gain (Nunn et al., 2012) and enhance competition, which could be mitigated by habitat diversity and presence of alternative resources (Pintar \& Resetarits, 2017).

Young of the year fish diet was partly composed by aquatic vegetation (i.e. bryophytes, spermaphytes, algae...), which could be important for some species (e.g. 25-29\% of the larval diet for common bleak). This low-energy food contributed more to YOY fish diet in the more heavily channelised reach. Adult diet also differed according to the studied site. In the less channelised reach, the diet of the four species comprised mostly benthic macroinvertebrates, while, in the other site, macroinvertebrates were less consumed and feeding on aquatic vegetation and on small fish contributed more to adult diets. At Waulsort, almost half of the diet of European perch, chub and roach was composed by YOY fish, while at Hamsur-Meuse this proportion was $<20 \%$ even for the European perch, which is known to prey upon fish larvae in addition to macroinvertebrates (Linzmaier, Twardochleb, Olden, Mehner, \& Arlinghaus, 2018). Fish feeding habits at Waulsort could be linked with lower availability of benthic macroinvertebrates, and with higher competition for food between consumers. The poor habitat structural complexity could also have facilitated predation on YOY fish at Waulsort, by increasing the foraging success of multiple predator species (Warfe \& Barmuta, 2004). Therefore, YOY were potentially affected by both low food availability and high predation risk.

In the absence of planktonic resources, YOY cyprinids mostly consumed the same resources whatever their ontogenic stages (i.e. larval or juvenile). Theoretically, when resource availability is reduced, fish trophic niche width tends to increase due to the diminution of their preferred diet (Bison et al., 2015). Juvenile fish generally consumed a broader range of prey types (zooplankton, macroinvertebrate larvae...) than larvae. Older YOY probably easily feed on a wide range of prey due to a larger mouth size and improved mobility (Nunn et al., 2012). However, we found that trophic niche areas of the two ontogenic stages studied were similar regardless of the site. Niche overlap, however, was higher for larvae. This provides some evidence that the
FIGURE 4 Relationship between the isotopic niche area $\left(\mathrm{SEA}_{\mathrm{C}}\right)$ and the cumulative overlap area between isotopic niches of four species of fish captured on two sites of the Meuse River differing by the degree of regulation, in 2013 and 2014 [Colour figure can be viewed at wileyonlinelibrary.com]
Ham sur Meuse

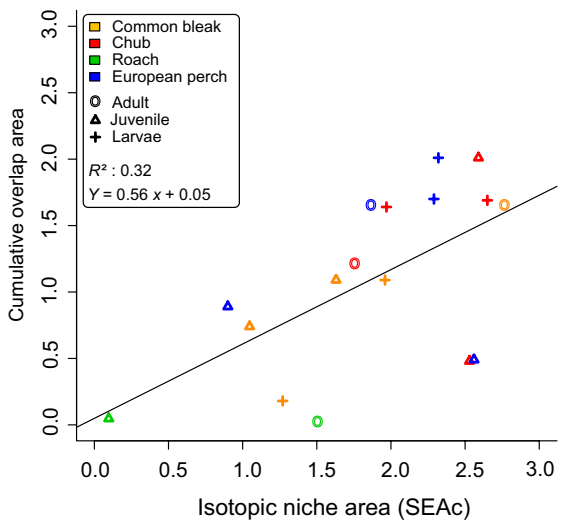

Waulsort

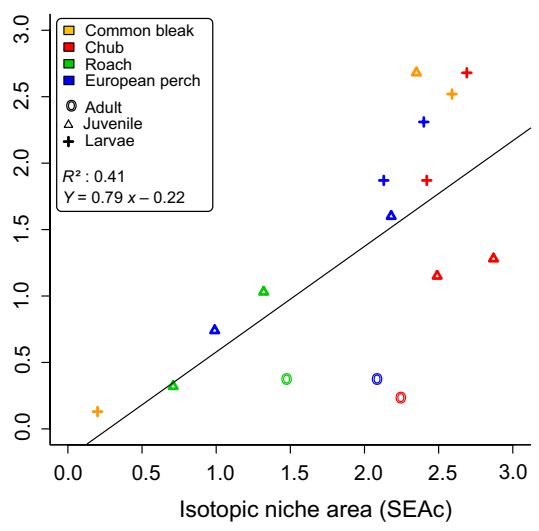



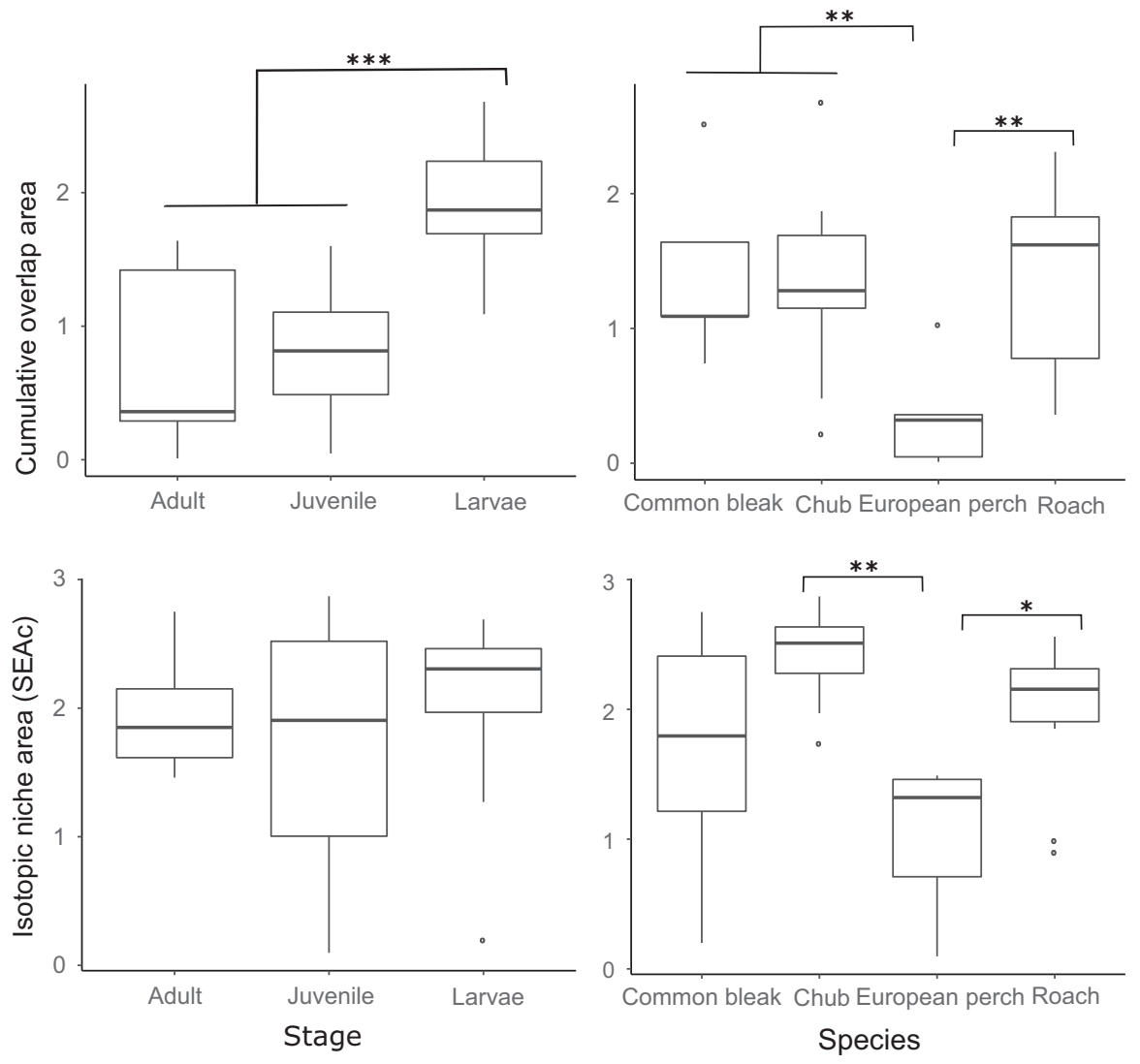

FIGURE 5 Comparison of the isotopic niche area $\left(S E A_{C}\right)$ and the cumulative overlap area between isotopic niches of four species of fish captured on two sites in 2013 and 2014. The significance of the interaction was tested using a generalised linear model $\left({ }^{*} p<.05,{ }^{* *} p<.01\right.$, $\left.{ }^{* * *} p<.001\right)$
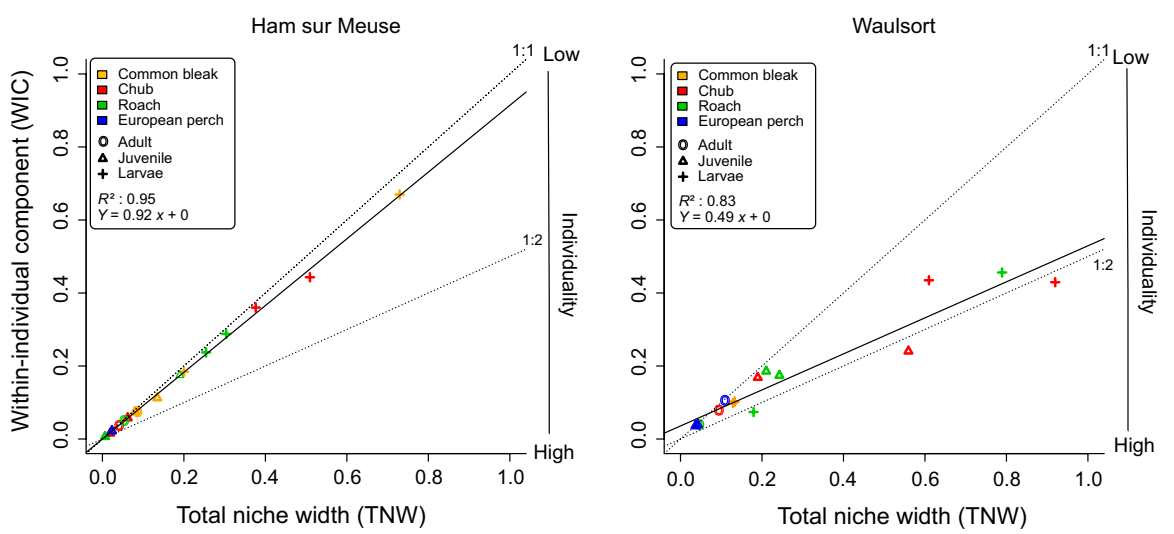

FIGURE 6 Relationship between the total isotopic niche width (TNW) and the within-individual component (WIC) of four species of fish captured on two sites of the Meuse River by the degree of regulation during 2013 and 2014. The slope of the relationship (solid lines) is an indicator of the dietary specialisation of the populations [Colour figure can be viewed at wileyonlinelibrary.com]

plankton diminution reduced the larval diet diversity, causing them to forage on other resources, such as benthic macroinvertebrates, which are also coveted by juveniles (Nunn et al., 2007a). Larvae were potentially constrained towards greater herbivory, which could have been less metabolically efficient and might have decreased growth rates (Post \& Parkinson, 2001).

Trophic competition and predation risk promoted diet plasticity, which could impact less competitive species such as common bleak (Lammens \& Hoogenboezem, 1991). In the Meuse River, YOY and adult abundance of common bleak decreased since the 1990s in the heavily channelised reach (Benitez et al., 2015), potentially due to the increase of great cormorant abundance and the decrease of planktonic resources (Latli, Descy et al., 2017). Conversely, the low plankton availability recorded in the Meuse River affected the trophic niche of the European perch in Waulsort differently. Contrary to YOY cyprinids, perch juveniles had a smaller isotopic niche, which means that they consumed less diverse resources; they mainly focused on benthic macroinvertebrates and YOY fish prey. Furthermore, European perch seemed less affected by the interspecific competition, as their niche overlap was smaller than the one of cyprinids. Due to an early hatching and a rapid growth (Pinder, 2001), young perches could swallow fish larvae and large benthic macroinvertebrates potentially inaccessible to other YOY taxa (Persson \& Hansson, 1999).

Even though food depletion could increase mortality, it is rarely observed because food competition generally favours diet partition between consumers (Olsson, Svanbäck, \& Eklöv, 2006). Moreover, intensification of trophic competition does not necessarily entail any effect on the population niche, but can instead promote diet 

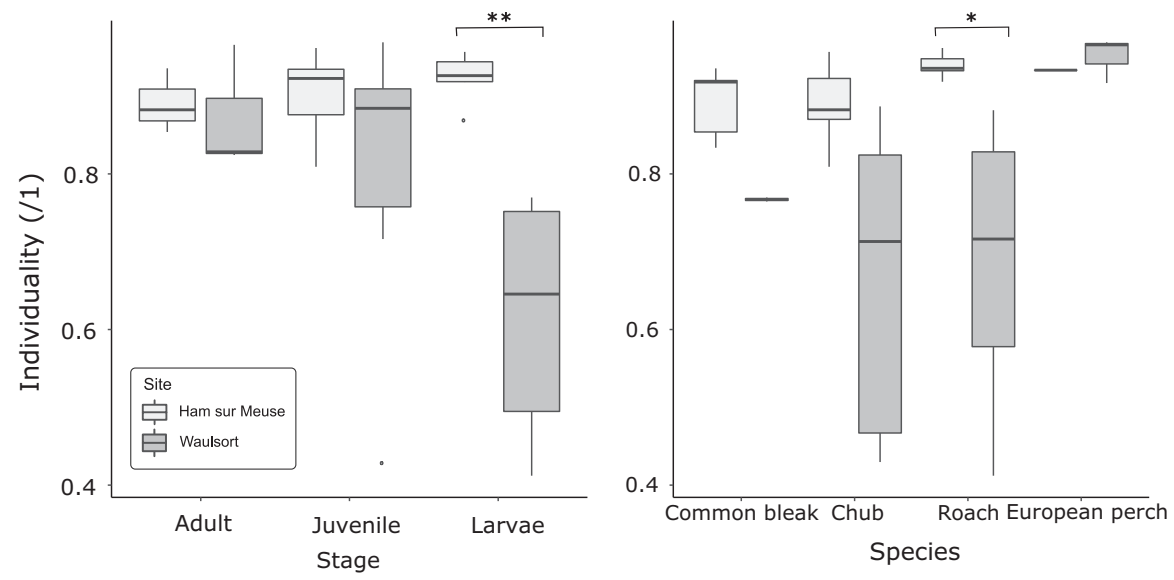

FIGURE 7 Comparison of dietary specialisation (within-individual component/total isotopic niche width) by life stage and species for four species of fish captured at two sites on the Meuse River in 2013 and 2014. Lower values indicate greater specialisation. The significance of the relationship was tested using a generalised linear model $\left({ }^{*} p<.05,{ }^{* *} p<.01,{ }^{* * *} p<.001\right)$

diversification within a population, i.e. IS (Araújo et al., 2011; Bolnick et al., 2010). Here, larval isotopic niche widths (a proxy of the diversity of resources used by a population) were similar between sites. However, channelisation induces individual trophic specialisation of larvae. In the less regulated reach, cyprinid larvae had a generalist diet, while in the heavily channelised reach individuals exhibited a more specialised diet oriented towards several macroinvertebrate taxa or aquatic vegetation. Many authors reported that IS is a way to reduce trophic competition (Araújo et al., 2011; Dias, Ortega, Gomes, \& Agostinho, 2017). In the channelised reach of the Meuse River, larval specialisation seems to be a way to deal with plankton rarefaction and increased trophic competition for macroinvertebrates with older stages of fish. Despite the fact that abundance of YOY cyprinids was similar in the two sites, all larvae from Ham-sur-Meuse focused on their optimal source food, i.e. a large panel of macroinvertebrate taxa. At Waulsort, low habitat diversity probably increased the resource partitioning between YOY (Marklund, Svanbäck, Zha, Scharnweber, \& Eklöv, 2018) and forced the less competitive stages (i.e. larvae) to consume less energetic food sources as bryophytes and algae.

Early life stages are critical periods for many organisms, and they require more accurate study to improve our understanding of community ecology and ecosystem functioning in a framework of human disturbances (Mapes et al., 2015). This study highlights the key role of intraspecific resource repartition for YOY fish having to cope with plankton-depleted conditions. Younger cyprinid stages seem more affected by intra- and inter-specific competition in the more channelised reach. YOY fish communities were also less diversified and abundant in the more altered site, which highlight the importance of limiting channelisation to better conserve fish communities.

\section{ACKNOWLEDGMENTS}

We especially thank André Evrard and Sacha Antipine for their support during the sampling. Thanks also to the anonymous reviewers for their contributions to improving this study. This work was partly supported by the Public Service of Wallonia and the European Fisheries Fund (contract FEP 32-1109-004). G.L. is appointed by the Belgian National Fund for Scientific Research (FRS-FNRS).

\section{ORCID}

Adrien Latli iD https://orcid.org/0000-0001-6640-5930

Loïc N. Michel iD https://orcid.org/0000-0003-0988-7050

Gilles Lepoint (iD https://orcid.org/0000-0003-4375-0357

Patrick Kestemont (iD https://orcid.org/0000-0002-0682-2844

\section{REFERENCES}

Aarts, B. G. W., Van Den Brink, F. W. B., \& Nienhuis, P. H. (2004). Habitat loss as the main cause of the slow recovery of fish faunas of regulated large rivers in Europe: The transversal floodplain gradient. River Research and Applications, 20, 3-23. https://doi.org/10.1002/rra.720

Alonso, J., Mougenez, S., \& Delattre, C. (2014). Tendances d'évolution du peuplement de poissons de la Meuse à Chooz de 1991 à 2008. Hydroécologie Appliquée, 18, 81-109. https://doi.org/10.1051/ hydro/2013053

Araújo, M. S., Bolnick, D. I., \& Layman, C. A. (2011). The ecological causes of individual specialisation. Ecology Letters, 14, 948-958. https://doi. org/10.1111/j.1461-0248.2011.01662.x

Araújo, M. S., Bolnick, D. I., Machado, G., Giaretta, A. A., \& dos Reis, S. F. (2007). Using $\delta 13 C$ stable isotopes to quantify individual-level diet variation. Oecologia, 152, 643-654. https://doi.org/10.1007/ s00442-007-0687-1

Bass, J. A. B., Pinder, L. C. V., \& Leach, D. V. (1997). Temporal and spatial variation in zooplankton populations in the River Great Ouse: An ephemeral food resource for larval and juvenile fish. Regulated Rivers: Research \& Management, 13, 245-258. https://doi.org/10.1002/ (sici)1099-1646(199705)13:3<245:aid-rrr452>3.0.co;2-p

Benitez, J., Dierckx, A., Nzau Matondo, B., \& Ovidio, M. (2015). Historical evolution of fish biodiversity and capture periodicity in the River Meuse (Belgium) as revealed by 15 consecutive years of fishpass 
monitoring. In International conference on river connectivity best practices and innovations. http://hdl.handle.net/2268/184994

Bison, M., Ibanez, S., Redjadj, C., Boyer, F., Coissac, E., Miquel, C., ... Loison, A. (2015). Upscaling the niche variation hypothesis from the intra- to the inter-specific level. Oecologia, 179, 835-842. https://doi. org/10.1007/s00442-015-3390-7

Bolnick, D. I., Ingram, T., Stutz, W. E., Snowberg, L. K., Lau, O. L., \& Paull, J. S. (2010). Ecological release from interspecific competition leads to decoupled changes in population and individual niche width. Proceedings of the Royal Society B: Biological Sciences, 277, 1789-1797. https://doi.org/10.1098/rspb.2010.0018

Bolnick, D. I., Svanbäck, R., Fordyce, J. A., Yang, L. H., Davis, J. M., Hulsey, C. D., \& Forister, M. L. (2003). The ecology of individuals: Incidence and implications of individual specialization. The American Naturalist, 161, 1-28. https://doi.org/10.1086/343878

Bolnick, D. I., Yang, L. H., Fordyce, J. A., Davis, J. M., \& Svanbäck, R. (2002). Measuring individual-level resource specialization. Ecology, 83, 2936-2941. https://doi.org/10.1890/0012-9658(2002) 083[2936:MILR

Caut, S., Angulo, E., \& Courchamp, F. (2009). Variation in discrimination factors ( $\Delta 15 \mathrm{~N}$ and $\Delta 13 \mathrm{C}$ ): The effect of diet isotopic values and applications for diet reconstruction. Journal of Applied Ecology, 46, 443-453. https://doi.org/10.1111/j.1365-2664.2009.01620.x

Coplen, T. B. (2011). Guidelines and recommended terms for expression of stable-isotope-ratio and gas-ratio measurement results. Rapid Communications in Mass Spectrometry, 25, 2538-2560. https://doi. org/10.1002/rcm.5129

Copp, G. H. (1997). Microhabitat use of fish larvae and $0+$ juveniles in a highly regulated section of the River Great Ouse. Regulated Rivers: Research \& Management, 13, 267-276. https://doi.org/10.1002/ (sici)1099-1646(199705)13:3<267:aid-rrr454>3.0.co;2-b

Copp, G. H. (2010). Patterns of diel activity and species richness in young and small fishes of European streams: A review of 20 years of point abundance sampling by electrofishing. Fish and Fisheries, 11, 439460. https://doi.org/10.1111/j.1467-2979.2010.00370.x

Descy, J.-P. (2009). Continental Atlantic Rivers. In K. Tockner, U. Uehlinger \& C. T. Robinson (Eds.), Rivers of Europe (pp. 151-199). London, UK, Burlington, USA, San Diego, USA: Elsevier Ltd.

Dias, R. M., Ortega, J. C. G., Gomes, L. C., \& Agostinho, A. A. (2017). Trophic relationships in fish assemblages of Neotropical floodplain lakes: Selectivity and feeding overlap mediated by food availability. Iheringia. Série Zoologia, 107, 11. https://doi.org/10.1590/1678-4766e2017035

Fewster, R. M., Buckland, S. T., Siriwardena, G. M., Baillie, S. R., \& Wilson, J. D. (2000). Analysis of population trends for farmland birds using generalized additive models. Ecology, 81, 1970-1984. https://doi. org/10.1890/0012-9658(2000) 081[1970:AOPTFF]2.0.CO;2

Higgins, S. N., Vander Zanden, M. J., Joppa, L. N., \& Vadeboncoeur, Y. (2011). The effect of dreissenid invasions on chlorophyll and the chlorophyll: Total phosphorus ratio in north-temperate lakes. Canadian Journal of Fisheries and Aquatic Sciences, 68, 319-329. https://doi. org/10.1139/f10-134

Hoogenboezem, W., Lammens, E. H. R. R., van Vugt, Y., \& Osse, J. W. M. (1992). A model for switching between particulate-feeding and filterfeeding in the common bream, Abramis brama. Environmental Biology of Fishes, 33, 13-21. https://doi.org/10.1007/bf00002549

Jackson, A. L., Inger, R., Parnell, A. C., \& Bearhop, S. (2011). Comparing isotopic niche widths among and within communities: SIBER - Stable Isotope Bayesian Ellipses in R. Journal of Animal Ecology, 80, 595-602. https://doi.org/10.1111/j.1365-2656.2011.01806.x

Johnson, J. H., \& McKenna, J. E. (2007). Diel periodicity of drift of larval fishes in tributaries of Lake Ontario. Journal of Freshwater Ecology, 22, 347-350. https://doi.org/10.1080/02705060.2007.9665057

Jurajda, P., Reichard, M., Hohausová, E., \& Černý, J. (2001). Comparison of $0+$ fish communities between regulated-channelized and floodplain stretches of the River Morava. Large Rivers, 12, 187-202.
Keckeis, H., Winkler, G., Flore, L., Reckendorfer, W., \& Schiemer, F. (1997). Spatial and seasonal characteristics of $0+$ fish nursery habitats of nase, Chondrostoma nasus in the River Danube, Austria. Folia Zoologica, 46, 133-150.

Kernaléguen, L., Arnould, J. P. Y., Guinet, C., \& Cherel, Y. (2015). Determinants of individual foraging specialization in large marine vertebrates, the Antarctic and subantarctic fur seals. Journal of Animal Ecology, 84, 1081-1091. https://doi.org/10.1111/1365-2656.12347

Konrad, G., De Leeuw, J., Winter, H., Khoruzhaya, V., Boldyrev, V., Vekhov, D., \& Nagelkerke, L. (2016). The importance of flooded terrestrial habitats for larval fish in a semi-natural large floodplain (Volga, Russian Federation). Inland Waters, 6, 105-110. https://doi. org/10.5268/iw-6.1.914

Lammens, E. H. R. R., \& Hoogenboezem, W. (1991). Diets and feeding behaviour. In Springer (Ed.), Fish \& fisheries series (pp. 353-376). Dordrecht, the Netherlands: Springer. https://doi. org/10.1007/978-94-011-3092-9_12

Latli, A., Descy, J.-P., Mondy, C. P., Floury, M., Viroux, L., Otjacques, W., ... Kestemont, P. (2017). Long-term trends in trait structure of riverine communities facing predation risk increase and trophic resource decline. Ecological Applications, 27, 2458-2474. https://doi. org/10.1002/eap.1621

Latli, A., Michel, L. N., Mathieu, F., Jonathan, M., Lepoint, G., \& Patrick, K. (2018). Impacts of reduced habitat diversity and impaired phytoplankton availability on large-river food web functioning. On Review.

Latli, A., Sturaro, N., Desjardin, N., Michel, L. N., Otjacques, W., Lepoint, G., \& Kestemont, P. (2017). Isotopic half-life and enrichment factor in two species of European freshwater fish larvae: An experimental approach. Rapid Communications in Mass Spectrometry, 31, 685-692. https://doi.org/10.1002/rcm.7838

Layman, C. A., Quattrochi, J. P., Peyer, C. M., \& Allgeier, J. E. (2007). Niche width collapse in a resilient top predator following ecosystem fragmentation. Ecology Letters, 10, 937-944. https://doi. org/10.1111/j.1461-0248.2007.01087.x

Lecerf, A., Baudoin, J.-M., Besson, A. A., Lamothe, S., \& Lagrue, C. (2012). Is smaller necessarily better? Effects of small-scale forest harvesting on stream ecosystems. Annales de Limnologie - International Journal of Limnology, 48, 401-409. https://doi.org/10.1051/limn/2012028

Lechner, A., Keckeis, H., \& Humphries, P. (2016). Patterns and processes in the drift of early developmental stages of fish in rivers: A review. Reviews in Fish Biology and Fisheries, 26, 471-489. https://doi. org/10.1007/s11160-016-9437-y

Lenth, R. V. (2016). Least-squares means: The R package Ismeans. Journal of Statistical Software, 69, 1-33. https://doi.org/10.18637/jss.v069. i01

Linzmaier, S. M., Twardochleb, L. A., Olden, J. D., Mehner, T., \& Arlinghaus, R. (2018). Size-dependent foraging niches of European Perch Perca fluviatilis (Linnaeus, 1758) and North American Yellow Perch Perca flavescens (Mitchill, 1814). Environmental Biology of Fishes, 101(), 2337. https://doi.org/10.1007/s10641-017-0678-y

MacArthur, R. H., \& Pianka, E. R. (1966). On optimal use of a patchy environment. The American Naturalist, 100, 603-609. https://doi. org/10.1086/282454

Mapes, R. L., DuFour, M. R., Pritt, J. J., \& Mayer, C. M. (2015). Larval fish assemblage recovery: A reflection of environmental change in a large degraded river. Restoration Ecology, 23, 85-93. https://doi. org/10.1111/rec.12138

Marescaux, J., Latli, A., Lorquet, J., Virgo, J., Van Doninck, K., \& Beisel, J.-N. (2016). Benthic macro-invertebrate fauna associated with Dreissena mussels in the Meuse River: From incapacitating relationships to facilitation. Aquatic Ecology, 50, 15-28. https://doi. org/10.1007/s10452-015-9540-5

Marklund, M. H. K., Svanbäck, R., Zha, Y., Scharnweber, K., \& Eklöv, P. (2018). The influence of habitat accessibility on the dietary and 
morphological specialisation of an aquatic predator. Oikos, 127, 160169. https://doi.org/10.1111/oik.04094

Nagayama, S., \& Nakamura, F. (2018). The significance of meandering channel to habitat diversity and fish assemblage: A case study in the Shibetsu River, northern Japan. Limnology, 19, 7-20. https://doi. org/10.1007/s10201-017-0512-4

Nakazawa, T. (2015). Ontogenetic niche shifts matter in community ecology: A review and future perspectives. Population Ecology, 57, 347-354. https://doi.org/10.1007/s10144-014-0448-z

Nunn, A. D., Harvey, J. P., \& Cowx, I. G. (2007a). The food and feeding relationships of larval and $0+$ year juvenile fishes in lowland rivers and connected waterbodies. I. Ontogenetic shifts and interspecific diet similarity. Journal of Fish Biology, 70, 726-742. https://doi. org/10.1111/j.1095-8649.2007.01334.x

Nunn, A. D., Harvey, J. P., \& Cowx, I. G. (2007b). The food and feeding relationships of larval and $0+$ year juvenile fishes in lowland rivers and connected waterbodies. II. Prey selection and the influence of gape. Journal of Fish Biology, 70, 743-757. https://doi.org/10.1111/j.1095-8649.2007.01335.x

Nunn, A. D., Tewson, L. H., \& Cowx, I. G. (2012). The foraging ecology of larval and juvenile fishes. Reviews in Fish Biology and Fisheries, 22, 377-408. https://doi.org/10.1007/s11160-011-9240-8

Olsson, J., Svanbäck, R., \& Eklöv, P. (2006). Growth rate constrain morphological divergence when driven by competition. Oikos, 115, 1522. https://doi.org/10.1111/j.2006.0030-1299.14965.x

Otjacques, W., De Laender, F., \& Kestemont, P. (2016). Discerning the causes of a decline in a common European fish, the roach (Rutilus rutilus L.): A modelling approach. Ecological Modelling, 322, 92-100. https://doi.org/10.1016/j.ecolmodel.2015.12.002

Otjacques, W., Latli, A., Bernard, B., Ovidio, M., Depiereux, E., \& Kestemont, P. (2015). Recent decline of roach Rutilus rutilus stock in a large river ecosystem in relation with its population dynamics. Fundamental and Applied Limnology, 187, 13. https://doi.org/10.1127/fal/2015/0830

Pavlov, D. S., Mikheev, V. N., Lupandin, A. I., \& Skorobogatov, M. A. (2008). Ecological and behavioural influences on juvenile fish migrations in regulated rivers: A review of experimental and field studies. Hydrobiologia, 609, 125. https://doi.org/10.1007/ s10750-008-9396-y

Persson, A., \& Hansson, L.-A. (1999). Diet shift in fish following competitive release. Canadian Journal of Fisheries and Aquatic Sciences, 56, 70-78. https://doi.org/10.1139/f98-141

Phillips, D. L., Inger, R., Bearhop, S., Jackson, A. L., Moore, J. W., Parnell, A. C., ... Ward, E. J. (2014). Best practices for use of stable isotope mixing models in food-web studies. Canadian Journal of Zoology, 92, 823-835. https://doi.org/10.1139/cjz-2014-0127

Pianka, E. (1974). Niche overlap and diffuse competition. Proceedings of the National Academy of Sciences of the United States of America, 71, 2141-2145. https://doi.org/10.1073/pnas.71.5.2141

Pianka, E. (1981). Competition and niche theory. Ariel, 128, 172-205.

Pigneur, L.-M., Falisse, E., Roland, K., Everbecq, E., Deliège, J.-F., Smitz, J. S., ... Descy, J.-P. (2014). Impact of invasive Asian clams, Corbicula spp., on a large river ecosystem. Freshwater Biology, 59, 573-583. https://doi. org/10.1111/fwb.12286

Pinder, A. C., \& Freshwater Biological Association (2001). In D. W. Sutcliffe (Ed.), Keys to larval and juvenile stages of coarse fishes from fresh waters in the British Isles. (Scientific). UK: Freshwater Biological Association. Retrieved from http://agris.fao.org/agris-search/search. do? recordID=XF2015020998

Pintar, M. R., \& Resetarits, W. J. (2017). Prey-driven control of predator assemblages: Zooplankton abundance drives aquatic beetle colonization. Ecology, 98, 2201-2215. https://doi.org/10.1002/ecy.1914

Post, J. R., \& Parkinson, E. A. (2001). Energy allocation strategy in young fish: Allometry and survival. Ecology, 82, 1040-1051. https://doi. org/10.1890/0012-9658(2001) 082[1040:EASIYF]2.0.CO;2

R Development Core Team (2015). R internals. R Development Core Team, 1, 63. https://doi.org/3-900051-14-3
Reckendorder, W., Keckeis, H., Tiitu, V., Winkler, G., Zornig, H., \& Schiemer, F. (2001). Diet shifts in $0+$ nase, Chondrostoma nasus: Sizespecific differences and the effect of food. Archiv für Hydrobiologie Supplement, 13512, 425-440.

Rudolf, V. H. W., \& Lafferty, K. D. (2011). Stage structure alters how complexity affects stability of ecological networks. Ecology Letters, 14, 75-79. https://doi.org/10.1111/j.1461-0248.2010.01558.x

Schiemer, F., Spindler, T., Wintersberger, H., Schneider, A., \& Chovanec, A. (1991). Fish fry associations: Important indicators for the ecological status of large rivers. SIL Proceedings, 1922-2010, 24, 2497-2500. https://doi.org/10.1080/03680770.1989.11899997

Shapiro, S., \& Wilk, M. (1965). An analysis of variance test for normality (complete samples). Biometrika, 52, 591-611. Retrieved from http:// www.jstor.org/stable/2333709

Stock, B., \& Semmens, B. (2013). MixSIAR GUI User Manual, version 1.0. Available from http://Conserver.lugo-Cafe.Org/User/Brice. Semmens/MixSIAR, 59. https://doi.org/10.5281/zenodo.594910

Valová, Z., Jurajda, P., \& Janáč, M. (2006). Spatial distribution of $0+$ juvenile fish in differently modified lowland rivers. Folia Zoologica, 55, 293-308.

Ward, J. M., \& Ricciardi, A. (2007). Impacts of Dreissena invasions on benthic macroinvertebrate communities: A meta-analysis. Diversity and Distributions, 13, 155-165. https://doi.org/10.1111/j.1472-4642.2007. 00336.x

Warfe, D. M., \& Barmuta, L. A. (2004). Habitat structural complexity mediates the foraging success of multiple predator species. Oecologia, 141, 171-178. https://doi.org/10.1007/s00442-004-1644-x

Way, C. M., Hornbach, D. J., Miller-Way, C. A., Payne, B. S., \& Miller, A. C. (1990). Dynamics of filter feeding in Corbicula fluminea (Bivalvia: Corbiculidae). Canadian Journal of Zoology, 68, 115-120. https://doi. org/10.1139/z90-016

Wedderburn, S. D., Hammer, M. P., Bice, C. M., Lloyd, L. N., Whiterod, N. S., \& Zampatti, B. P. (2017). Flow regulation simplifies a lowland fish assemblage in the Lower River Murray, South Australia. Transactions of the Royal Society of South Australia, 141, 169-192. https://doi.org/1 0.1080/03721426.2017.1373411

Yurkowski, D. J., Ferguson, S., Choy, E. S., Loseto, L. L., Brown, T. M., Muir, D. C. G., ... Fisk, A. T. (2016). Latitudinal variation in ecological opportunity and intraspecific competition indicates differences in niche variability and diet specialization of Arctic marine predators. Ecology and Evolution, 6, 1666-1678. https://doi.org/10.1002/ece3.1980

Zaccarelli, N., Bolnick, D. I., \& Mancinelli, G. (2013). RInSp: An R package for the analysis of individual specialization in resource use. Methods in Ecology and Evolution, 4, 1018-1023. https://doi. org/10.1111/2041-210x.12079

Zuur, A. F., leno, E. N., Walker, N., Saveliev, A. A., \& Smith, G. M. (2009). Mixed effects models and extensions in ecology with R. Mixed effects models. New York, NY: Springer New York. https://doi. org/10.1007/978-0-387-87458-6

\section{SUPPORTING INFORMATION}

Additional supporting information may be found online in the Supporting Information section at the end of the article.

How to cite this article: Latli A, Michel LN, Lepoint G,

Kestemont P. River habitat homogenisation enhances trophic competition and promotes individual specialisation among young of the year fish. Freshw Biol. 2019;64:520-531. https:// doi.org/10.1111/fwb.13239 